Opinion

\title{
Role of Psychiatry Nurse in Anti-Manic Drugs
}

\author{
Mushtaq B* \\ Department of Psychaitry, PG Psychaitry Nursing Scholar, India
}

*Corresponding author: Mushtaq B, Departmnet of Psychaitry, PG Psychaitry

Nursing Scholar, Srinagar, India.

Received Date: September 06, 2018

Published Date: September 28, 2018

\section{Abstract}

Anti-manic drugs are the mood stabilizers that are used to treat mania. There are various types of drugs which are prescribed for anti-manic affect. There is need for the various observations like physiological changes to be monitored while giving these drugs and psychiatric nurse plays a very important role for observation of the various changes and providing appropriate interventions accordingly.

\begin{tabular}{|c|c|}
\hline Name of Drug & Nurses Role \\
\hline \multirow{6}{*}{ Carbamazepine } & 1. Monitor vital signs timely. \\
\hline & 2. Document and monitor input -output chart of the patient. \\
\hline & 3. Get all the baseline tests done on periodic basis like CBC, serum electrolytes, LFT, BUN etc. \\
\hline & $\begin{array}{l}\text { 4. Monitor for the reactions after the drug is given like drowsiness, dizziness, light-headedness, ataxia, } \\
\text { gastric upset. }\end{array}$ \\
\hline & $\begin{array}{l}\text { 5. Withhold the drug and notify the physician if you notice any of changes like: } \mathrm{RBC}<4 \text { million } / \mathrm{mm} 3, \mathrm{Hct} \\
<32 \% \text {, Hgb }<11 \mathrm{~g} / \mathrm{dL}, \mathrm{WBC}<4000 / \mathrm{mm} 3 \text {, platelet count }<100,000 / \mathrm{mm} 3 \text {, reticulocyte count }<20,000 / \\
\mathrm{mm} 3 \text {, serum iron }>150 \mathrm{mg} / \mathrm{dL} \text {. }\end{array}$ \\
\hline & 6. Monitor lithium toxicity. \\
\hline \multirow{4}{*}{$\begin{array}{l}\text { Divalproax } \\
\text { Sodium }\end{array}$} & a. Perform all baseline tests including platelet count, bleeding time. \\
\hline & b. Monitor keenly client during the dose adjustment and monitor the client for any adverse reactions. \\
\hline & $\begin{array}{l}\text { c. Multiple drugs for seizure control increase the risk of hyperammonemia, marked by lethargy, anorexia, } \\
\text { asterixis, increased seizure frequency, and vomiting. Report such symptoms promptly to physician. If } \\
\text { they persist with decreased dosage, the drug will be discontinued. }\end{array}$ \\
\hline & $\begin{array}{l}\text { d. Do not discontinue therapy abruptly, firstly discuss with Consult physician before you stop or alter } \\
\text { dosage regimen because this may lead to loss control over seizures }\end{array}$ \\
\hline \multirow{5}{*}{ Lamotrigine } & A. Monitor for any development of rashes and stop the drug immediately. \\
\hline & B. Monitor the plasma levels of lamotrigine when given with any another drug. \\
\hline & C. Also check for any adverse reaction \\
\hline & D. when lamotrigine is used with other anticonvulsants, especially valproic acid. \\
\hline & E. Be aware of drug interactions and closely monitor when interacting drugs are added or discontinued. \\
\hline \multirow{6}{*}{$\begin{array}{l}\text { Lithium } \\
\text { Carbonate }\end{array}$} & 1. Monitor older adults carefully to prevent toxicity as they may not tolerate the toxicity. \\
\hline & 2. Monitor timely the occurrence of hypothyroidism. \\
\hline & 3. Weight the patient daily. \\
\hline & 4. Check ankles, tibiae, and wrists for edema. \\
\hline & 5. Maintain input-output chart. \\
\hline & 6. Report early signs of extrapyramidal reactions promptly to physician. \\
\hline
\end{tabular}

\section{Conclusion}

As psychiatric nurse is the personnel to be in close proximity and to have close watch for the clients having mania, so the drugs given should be completely supervised by the psychiatric nurse as these drugs have various side-effects which can be threatening to the client. 